\title{
Publisher Correction: Probing molecule-like isolated octahedra via phase stabilization of zero- dimensional cesium lead halide nanocrystals
}

Paulraj Arunkumar (DD ${ }^{1}$, Han Bin Cho ${ }^{1}$, Kyeong Hun Gil ${ }^{1}$, Sanjith Unithrattil ${ }^{1}$, Yoon Hwa Kim ${ }^{1}$ \& Won Bin Im (D) ${ }^{1}$

Correction to: Nature Communications; https://doi.org/10.1038/s41467-018-07097-x, published online 08 November 2018

The original version of this Article contained an error in the title, which incorrectly read 'Probing molecule-like isolated octahedra via - phase stabilization of zero-dimensional cesium lead halide nanocrystals.' The correct version states 'via phase stabilization' in place of 'via-phase stabilization'. This has been corrected in both the PDF and HTML versions of the Article.

Published online: 17 December 2018

\begin{abstract}
(c) (i) Open Access This article is licensed under a Creative Commons Attribution 4.0 International License, which permits use, sharing, adaptation, distribution and reproduction in any medium or format, as long as you give appropriate credit to the original author(s) and the source, provide a link to the Creative Commons license, and indicate if changes were made. The images or other third party material in this article are included in the article's Creative Commons license, unless indicated otherwise in a credit line to the material. If material is not included in the article's Creative Commons license and your intended use is not permitted by statutory regulation or exceeds the permitted use, you will need to obtain permission directly from the copyright holder. To view a copy of this license, visit http://creativecommons.org/licenses/by/4.0/.
\end{abstract}

(c) The Author(s) 2018 